\title{
Pathological Quiz
}

\section{Lt Col JJJ Falleiro, SM*, Dr Sachin Jain+, Lt Col D Bhattacharyya*, Lt Col RB Deoskar*, Col KE Rajan++, Col MP Muttagikar"}

MJAFI 2003; 59 : 245

\section{Clinical Information}

$\mathrm{T}$ his 25 year old serving soldier, was under treatment for pulmonary tuberculosis and Pneumocystis carinii pneumonia in the background of HIV infection. While on treatment, he developed low-grade intermittent fever, which lasted for two months. He was found to have tender, multiple, mobile, discrete, enlarged lymph nodes in the left cervical region, largest measuring $3 \times 4$ $\mathrm{cm}$. Ultrasonography of abdomen showed mesenteric lymph node enlargement without ascites or hepatomegaly. FNAC of lymph node from the left cervical region showed the picture given in Fig 1 (250x).

What is your diagnosis?

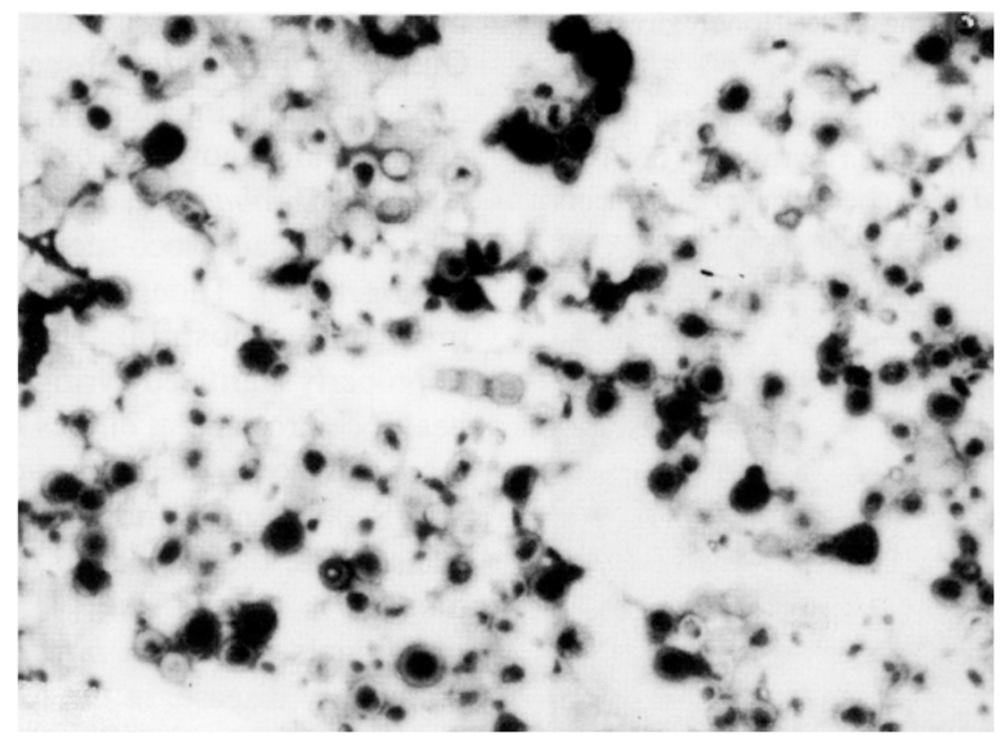

rig. 1:

Answer to the Pathological quiz - pg. 268

'Classified Specialist (Pathology), +Post Graduate Resident, "“Classified Specialist (Medicine and Respiratory Medicine), ${ }^{++}$Senior Advisor (Medicine and Respiratory Medicine), Military Hospital (CTC), Pune - 411040 , "Classified Specialist (Medicine), Military Hospital Namkum, "Senior Advisor (Pathology and Microbiology), Command Hospital, Southern Command, Pune - 411040. 


\section{Answer to Pathological Quiz}

FNAC of lymph node shows numerous capsulated yeast forms of varying size with budding, suggestive of Cryptococcus neoformans. The patient was treated with Amphotericin B. Patient responded well to therapy with regression of fever and regression of lymph nodes.

Cryptococcus neoformans is an encapsulated, yeast like fungus. Though Cryptococcus reproduces by budding, they are rarely seen in the specimen. Closely lying yeast cells may at times give false appearance of budding. The cell is round or oval, usually $4-6 \mu \mathrm{m}$ in diameter [1]. It is the most common life threatening fungal pathogen that infects patients with AIDS [2]. The usual response to the pathogen is stated to be granulomatous reaction. This need not be so in HIV infection. In this case there was no granulomatous response. It is the fourth most common infection in AIDS patient after Pneumocystis, Cytomeagalovirus and Mycobacterial disease. Three major clinical presentations of cryptococcosis include central nervous system involvement, pulmonary lesions and disseminated infection.

Disseminated infections include adrenal glands, skin, kidney and lymph node. Unusual manifestations include myocarditis, massive peripheral and mediastinal lymphadenopathy mimicking malignant lymphoma, isolated pleural effusion and biliary tract obstruction secondary to cryptococcal lymphadenitis [3].

\section{References}

1. Diamond RD. Cryptococcus neoformans. In : Mandell GL, Bennett JE, Dolin R, editors. Mandell, Douglas and Bennett's Principles and Practice of Infectious Diseases, $4^{\text {th }}$ ed. Churchill Livingstone 1995:2331-40.

2. Chuck JL, Sande MA. Infections with Cryptococcus neoformans in acquired immunodeficiency syndrome. N Engl J Med 1989;32I:794-9.

3. Finley JL, Joshi VV. Smith NL. General pathology of HIV infection. In : Wormser GP, editor. AIDS and other manifestations of HIV infection. $3^{\text {rd }} \mathrm{ed}$ Lippincott - Raven 1998;583-626. 